FileP TAMÁs GUSZTÁV*

\title{
„A néma ősök várócsarnoka”
}

\author{
„Prágai, csehországi születésü vagyok, apám tiszt volt. \\ Nincs hazám, otthonom a 48. gyalogezred..." \\ Johann Meschede honvéd örnagy 1849-ben, \\ a pesti hadbíróság előtt
}

Zoltán nagybátyámat, az ő Urának, a Jézus Krisztusnak méltatlan bár, de hivatalos szolgáját apám azzal ugratta egyszer, hogy úrvacsoraosztásnál a kenyeret bizonyára a hívek büneihez szabja; van, aki még nem tudta lenyomni a torkán az Úr testét, amikor ő már a serleget emeli elötte.

Én sem lehetek valami jámbor lélek; most arra ítéltek, hogy ne csak a hazámról beszéljek, hanem arról is, hogyan lett belőlem egy - a közvélekedés szerint legalábbis - félproli kerületben az úgynevezett „népi tábor” tagja.

A közvélemény viszont most sem elég megalapozott: a Ferencvárosnak - ideiglenes kényszerlakhelyemnek születésemtől, gondolom, a halálomig, ahonnan már nagyon régen nem tudnék elmenni -, ha nem is a kezdetektől, 1792-töl, de legkésőbb a reformkortól - van polgári-értelmiségi magja is. Kezdve a református gettóval a Kálvin tér környékén, a templommal - itt keresztelték József Attilát, akármennyire ortodoxnak gondolta is utóbb magát -, a teológiával, a Ráday Gyüjteménnyel, a Lónyay utcai ref. gimnáziummal, amely nevével ellentétben ma a Kinizsi utcában müködik, s amely a világszerte bizonyára legismertebb magyar regény egyik színhelye. Molnár Ferencen kívül például Szent-Györgyi Albert járt oda. Hogy Kosztolányi és Móricz Zsigmond itt élt, mindenki tudhatja, de megfordult itt a reformkori és a két világháború közötti írótársadalom java: a 19. század első felében a Belső-Ferencvárosban szerkesztették az Aurora zsebkönyvet - Kisfaludy Károly, Kazinczyval, Kölcseyvel, Vörösmartyval; az átellenben lévő házban Arany János lakott utóbb -, a 20.-ban pedig a Nyugatot. A századfordulón vagy másfél évtizedig itt volt az Eötvös Collegium székhelye. Vannak szabadságharcosaink és forradalmáraink - nemcsak 56-os felkelöközpontjaink; 1848. március 15-én innen ment át a tüntetők jó része a szomszédba, a Múzeum elé. 1853-ban itt végezték ki társaival együtt Noszlopy Gáspárt, a szabadságharc kormánybiztosát. Az első alkalmi számvetésből nem jövünk ki rosszul - van világhírü és -színvonalú írónk (szerintem több is), van Nobel-díjasunk; egyetemből, főiskolából van itt vagy * A szerző müvelödéstörténész, a Társadalomtudományi Kutatóközpont Kisebbségkutató Inté-
zet munkatársa. E-mail: FilepTamasGusztav@tk.hu 
öt. Nekem ugyan édesmindegy, hol áll a Nemzeti Színház, de amikor a belvárosi elit fölhördült, hogy az új épületet egy szellemi sivatagban húzzák föl, ezt nem tekinthettem tárgyszerünek; talán ekkor érzékeltem először közvetlenül a fővárosi szellemi partizánháború egyik korábban általam föl nem fedezett frontvonalát.

Ha a legrövidebb úton végigmegyünk a kutatóházból elindulva az Angyal utca 28-as számú házig, mire odaérünk, minden kiderül.

Haller utca. Kint a Duna-parton hasít Tornai Jóska régi versének hőse, az egykori vágóhidak idején vér- és koromszagú ferencvárosi szél. A Vaskapu utcán kijutva szemben egy vendéglátó-üzemegység, azelőtt kerületi ideggondozó; 130 lépésre tőle, a templom irányában, az innenső oldalon a kerületi rendőrkapitányság. Az egyikben besúgónak akartak beszervezni 1981-ben, a másikban jóval később antidepresszáns-recepteket vehettem át. Egyszer, míg orvosra várva az ideggondozó előtt cigarettáztam, azon tépelődtem, hogy az itt rólam nyert információk mennyi idő alatt s milyen formában jutnak át a másik épületbe. Beteszik őket egy táskába, és átsétálnak velük?

A Mester utcán a Ferenc körút felé haladva a jobb oldalon az első Fáy András-emlék, a „nemzet mindenese”, az első magyar takarékpénztár atyjának emléktáblája a róla elnevezett szakgimnázium homlokzatán. Elhagyva annak a túloldali háznak a vonalát, ahol Stromfeld Aurél, az 1919-es felvidéki hadjárat vezérkari fönöke élt, talán ötszáz lépéssel érünk a Bokréta utca sarkára. Befordulhatnánk, $\mathrm{s}$ tíz másodperc múlva ott állnánk a katolikus Szociális Testvérek Társasága volt nővédő otthonának kapuja elött. 1944-ben zsidó lányokat bújtattak itt; innen vitték el Salkaházi Sárát és Bernovits Vilmát négy védencükkel együtt, hogy még aznap este a Dunába lőjék őket. Nem fordulunk be; átmegyünk a túloldalra, a szemközti sarokházhoz, az iskolához, ahová rajtam kívül József Attila is járt; becslésem szerint akár ugyanazokban a padokban is ülhettünk. A saroképületet 56-ban kollégisták védték; november 5-én 13 óra 30 perc után ostrommal foglalták el a szovjet katonák. Csak magyar részről volt véres veszteség: egy halott diák.

A Mester utcáról tér hiányában ennyit. A Ferenc körút előtti utolsó utca volt a miénk. Magamtól nem árulnám el, de Krúdy Gyula már kifecsegte a titkát, a táj rejtélyes szellemeiről, a Cholnoky testvérekről írván: „Az Angyal utcában egy hordóba zárva tartogatnak egy pohos, vastag derekú ferencvárosi polgárt, aki a boszorkány szolgáló után bújt be egyszer a csaplyukon, és most minden jámbor keresztény emberek segítenek leinni a bort a fuldokló polgárról.”

Megint keresztutca. Kész csoda, hogy a Montblanc-ember, Vajda János nem pukkadt meg mérgében, amikor nem róla, hanem Tompa Mihályról nevezték el, holott ő írta itt a verseit, Az üstököst többek között. Az Angyal és a Tompa utca sarkán álló ház egyik lakásában, a színpad számüzött fejedelemasszonyánál élte át a 44-es ostrom egy részét - skót-görög feleségével együtt - Kemény János, a vécsi vár ura, az erdélyi Helikon írótársaság házigazdája. Később Gáli József, a forradalom leverése után halálraítélt író mozgott benne otthonosan. Amikor az úrnő a mi 
szuterénlakásunkba járt, e számomra fontos neveket jól ismertem már. Arról, hogy „szomszédok” voltunk, talán negyvenöt év múltán hallottam először.

Az Angyal utca 29-ben az Advent és a Boldogtalanok született Füst Milán fö művei közül. A 28-as szám alatti ház megvételére születésem után szerződtek a szüleim; a Bajcsy-Zsilinszky úti öreg főbérlők nem bírták a gyereksírást. Apám két évvel korábban, a börtönből való szabadulása után döntött úgy, hogy a fővárosba költözik családjával, eltünik a tömegben; ez volt a szabadlábra került 56-osok körében az egyik népszokás.

Nyilván Isten különös kegyelméből 1957-ben „népi demokratikus államrend megdöntésére irányuló szervezkedésben való részvételre vállalkozás" miatt föbüntetésként első fokon 5 évre ítélték. Végül 2 év 2 hónap 22 napig vett részt az „Ismerd meg hazád börtöneit” mozgalomban. Egy 1970-es törvényerejü rendelet alapján „mentesült a büntetett elóélethez füz. hátr. alol.” A semmisségi határozat keltezése 1990. február 16. - a diktatúra egyik utolsó pillanata.

A bükki hegylábfelszín egyik falujában éreztem legjobban magam; a Nagykunság félparaszti fóvárosában kellett volna felnőnöm papírforma szerint. A numerus clausust rám is kimondó párthatározat hivatalosan csak 1963-ig volt érvényben, hogy informálisan meddig, nem tudom. A születési anyakönyvi kivonatomban apám gépmunkásként szerepel, így, bár csak eltartottként, néhány évig az uralkodó osztály tagja lehettem. Magyarországon, úgy látom, súlyos szövegértelmezési problémákkal küzdenek, megjegyzem hát, hogy ez nem panaszkodás. Ez így nekem tökéletesen megfelelt. Megnyugtató, hogy pályatársaim némelyikével nem egy fazékban föttem.

Egy rövid idézet az „Ügynökünk jelenti” sorozat 1960-as epizódjából. A három jelenlévő másfél éve még együtt volt Vácon vagy a Gyüjtőfogházban; ketten

$1 \quad$ Egy sorozatgyilkos diktatúra kiszolgálása nyilván tetemesen növeli az érdekelt extraprofitját, de örökségemből példával is közvetlenül igazolhatni vélem, hogy egészségügyileg ellenjavallt.

Említettem, hogy az apám büntetett előéletéből származó hátrányok a hetvenes években megszüntek. Ez nem történt automatikusan. A népi demokrácia ismérvei közé tartozott, hogy a gyilkosság például akkor is elévült egy bizonyos idő után, ha a törvény keze nem tudott lecsapni az elkövetőre. A politikai bủnökkel egy ilyen rendszerben bonyolultabb a helyzet. Apámnak tehát meg kellett keresnie a Legfelsőbb Bíróságnak azt a bíróját, aki az eljárást másodfokon vezette, s aki 1956-os ügyekben a legtöbb halálos ítéletet hozta: 66-ot (az elsőfokú eljárás irányítója is ismert ember: kirendelt bíróként ő volt jelen Nagy Imréék kivégzésénél), hogy együtt indítsák el a jogi procedúrát. A bíró nagyjából a következőképpen fogadta:

- Drága Pistukám! De örülök, hogy megkerestél! Ezer éve nem láttalak!

Két magyarázatot találhatok erre:

1. „Az idő megszépít.” Nem kizárt, hogy ennek az ügynek két főszereplője számára nem egyforma mértékben.

2. Aki erkölcsileg is, jogilag is elfogadhatatlan ítélethez adja a nevét, s ezzel súlyos szenvedést okoz, előbb-utóbb megörül.

Alapjában humanista lévén, azt hiszem, ebben az esetben az utóbbi történt. 
tanárok, most koldusfillérekért végeznek fizikai munkát, a harmadik újságíró volt, most kényszerbesúgó. Jelenti megbízóinak: apám beszámol arról, hogy Darvas Iván éppen egy mủanyagprésüzemben dolgozik, a neki szerzett állásra viszont szükség lehet még, például Mensáros László hamarosan szabadul Márianosztráról. (Ifjúkorom nagy színészei voltak; talán van, akinek még ismerős ez a két név.) Aztán: „Filep megkérdezte, hogy melyikünk tud a nagyatádi erdőgazdaság fökönyvelöjéről [...] meg kellene tudni, szabadult-e már - mondta [...], mert tudomása szerint 4 vagy 5 gyermeke van, s ha még nem szabadult, meg kell szervezni családjának a segítését."

A haza. Évszámok - épp az elhangzottak is - és nevek. A kushadó társadalomban néhány emberrel megosztható magány - és szolidaritás. Életem értelmesebb részében ezért foglalkoztam a magyar kisebbségekkel.

Arcok, szövegek, hegyek, épületek enklávéláncolata.

Kissé fogalmibban, s kicsit kiforgatva Kantot: A csillagos ég és az erkölcsi törvény fölöttem.

Képszerübben, s programunk közös mottójához visszatérve: töredezett szegélyü, szakadozó, semmibe foszló bárányfelhő az égen. 